\title{
Effect of Transformational Leadership, Job Design, and Human Resource Practices on Job Satisfaction of Banking Staff in Pakistan
}

\author{
Amira Nasreen $^{1}$, Khawaja Khalid Mehmood $^{1}$
}

\begin{abstract}
Employee job satisfaction has been one of the crucial factors behind an organization's success. Review of literature in the field of management, leadership, and organization behavior regarding antecedents of job satisfaction indicates that job design, transformational leadership, and human resource practices are essential antecedents of job satisfaction as accounted for a variety of researches. However, there have been limited researches that study impact of job design, transformational leadership, and human resource practices on job satisfaction in one research outline. Further, literature review indicates that such research is warranted in Pakistan because there is extremely limited research on this topic in the context of Pakistan. To fulfil this research gap, this study took data from banking sector as this sector is considered to be essential one contributing to Pakistan economy; and job satisfaction among bank staff has always been an important concern. The study utilized final response of 170 questionnaires from various private banks in Southern Punjab, and relied on SmartPLS3.0 for analyses of data. The study suggests that job satisfaction is affected positively by human resource practices and transformational leadership, whereas job design does not affect job satisfaction in the banking context. This study makes invaluable contribution to transformational leadership theory, organization behavior, and dynamic capabilities perspective through its hypotheses testing. The study recommends banks' management to improve quality of human resource practices as well as concentrate on promoting transformational leadership style in their banks.

Keywords: Human Resource Practices, Job Design, Job Satisfaction, Transformational Leadership.

JEL Classification: J28, M12, M51, M52.
\end{abstract}

\section{Introduction}

The success of any organization depends directly or indirectly on the effort, capability, and contribution of its employees and leaders. Traditionally, among many factors contributing to organization's success, job satisfaction has been considered as one crucial factor (Conley, 1989; Hoy \& Miskel, 1987). Job satisfaction is about positive feelings regarding the job, or is whether an employee likes various facets or aspects of his job. For instance, the type of work and kind of supervision (Spector, 1997). As job satisfaction is an outcome, therefore, several factors such as task characteristics, dual-

${ }^{1}$ Institute of Management Sciences, Bahauddin Zakariya University, Multan, Pakistan

*Corresponding Author: khawjakhalid@bzu.edu.pk

OPEN This work is Licensed under a Creative Commons Attribution-Noncommercial 4.0 International License (4) (2)


attachment approaches, social information processing, and dispositional variables might determine job satisfaction (Baker, 2004; Savickas \& Savickas, 2016). This study investigated and identified important factors (transformational leadership, job design, and HR practices) with reference to organization behavior theory, transformational leadership theory, and dynamic capabilities perspective, considered crucial for job satisfaction and tested them in one research framework. Further, these variables have been considered relevant and important in context of Pakistan-based organizations as well (Abid, Sarwar, Imran, Jabbar, \& Hannan, 2013; Bushra, Ahmad, \& Naveed, 2011; Iqbal, Malik, \& Ghafoor, 2013; Islam, Bangish, Muhammad, \& Jehan, 2016). The study identifies that a gap lies in the previous research that under the theories mentioned above, the effects of transformational leadership, job design, and human resource practices have although been examined already, not in a single research framework, whereas this research accomplishes the purposes of testing these antecedents in the same research framework. Another gap lies in the form of context, that in the context of Pakistan, this kind of research has not been conducted before which actually could provide useful suggestions to bank managers in Pakistan regarding how they could manage job satisfaction of the banking staff in Pakistan.

Leadership is a connection that makes workers do their work collectively. According to scholars (Iliescu, Beldean, \& Sîntion, 2007; Khan et al., 2014), leadership exerts powerful control on the behavior of people and their attitude towards their profession. Transformational leadership is a contemporary concept in leadership theory. Historically, Burns (1978) proposed that transformational leader cares for his followers, shows high concern for them, and possesses capability to define mission and conceptualize vision. Bass (1985) included individualized consideration, idealized/charisma influence, intellectual stimulation, and inspirational motivation into the concept of transformational leadership. Empirical research has largely reported that transformational leaders are successful in increasing job satisfaction of their followers (al-Dumur \& al-Awamilah, 2002; Bushra et al., 2011).

Furthermore, satisfaction could be obtained by designing jobs better. Theories in organization behavior have proposed various methods of designing jobs to improve motivation and job satisfaction, such as job enlargement, job enrichment, and job rotation (Herzberg, 1966; Onimole, 2015). Herzberg (1966) suggested that jobs must be designed so that they could enable employees to improve their capability, clarify accountability, and provide sense of recognition and achievement. Researchers largely claim that job design affects job satisfaction (Fahr, 2011; Onimole, 2015; Sageer, Rafat, \& Agarwal, 2012). Moreover, researchers and experts acknowledge that higher degree of worker satisfaction could be obtained through HR practices that could eventually improve managerial and organizational performance (Appelbaum, Bailey, Berg, \& Kalleberg, 2000). Various scholars in different contexts have worked on various HR practices in the past. In Chinese context, Syed and Yan (2012) examined the effect of various HR practices on job satisfaction and reported that performance based salary,

Sukkur IBA Journal of Management and Business - SIJMB | Volume 5 No. 1 January - June 2018 @ Sukkur IBA University 
employee participation, merit based promotion, empowerment, job rotation, and complaint handling procedure had positive impact on job satisfaction. Petrescu and Simmons (2008) studied impact of pay and incentive systems on job satisfaction in British context. Nabi, Syduzzaman, and Munir (2016) examined impact of performance appraisal, training and development, teamwork, compensation, and employee participation on job satisfaction in context of Bangladesh. Empirical research largely concludes that HR practices have a significant positive effect on job satisfaction (Frye, 2004; Humborstad \& Perry, 2011; Kampkötter, 2017; Kosteas). In line with Mumtaz, Khan, Aslam, and Ahmad (2012), this research examines effect of four HR practices (compensation practices, promotion practices, empowerment practices, and performance appraisal practices) on job satisfaction.

This research is carried out in banking sector of Pakistan. This sector marked improvements that started since early 1990's and have now transformed banking sector into a comprehensive, sustainable, and well-organized structure. Banking system in Pakistan has been enhanced by high technology revolution and globalization. There are around 31 banks in Pakistan from which five are public sector banks. Concerning performance, the previous decade has been better for banking sector with the figures being favorable regarding balance-sheet growth for banks. As Michaels (2017) quotes, since 2009 to September, 2016, total assets increased to PKR 15,134 billion from PKR 6,516 billion; investments exponentially increased from PKR 1,737 billion to PKR 7,625 billion; total deposits increased to PKR 11,092 billion from PKR 4,786 billion; and lending rose to PKR 5,025 billion from PKR 3,240 billion. The industry structure indicates that a vast network of banks' branches is maintaining strong competition among the banks. Empirical research in organization behavior and human resource practices conducted in banking sector all over the world indicates this sector's importance and also points towards relevancy of this research's variables to the nature of banking jobs. Therefore, this research adds to relevant theories as well as provides recommendations for banks' management for improving job satisfaction of banking staff, particularly in Pakistan.

\section{Literature Review}

As argued earlier, job satisfaction is about feeling positive about the job, or is whether an employee likes various facets or aspects of his job such as the type of work and kind of supervision (Spector, 1997). Research has been focusing on job satisfaction since 1935 (Vroom, 1964). A number of factors could affect job satisfaction, and different researchers have identified various antecedents of job satisfaction as well. Herzberg (1966) suggested that recognition, development, responsibility, accomplishment, and job itself were five significant aspects responsible for job satisfaction, out of which at least three factors must be met. Researchers argue that employees feel more satisfied in conditions like when they feel they possess relevant skills, when they like organizational procedures, and they feel their requirements are being fulfilled. This

Sukkur IBA Journal of Management and Business - SIJMB | Volume 5 No. 1 January - June 2018 @ Sukkur IBA University 
research, however, focuses on the side of leadership, HR practices, and job design based on the theories already mentioned.

\subsection{Transformational leadership and job satisfaction}

Leadership has been crucial to organizations. Effective leaders definitely enhance company's productivity and employee satisfaction. Different managers have different leadership styles that might be related differently with people's satisfaction and organizational performance. Relationship between leader and followers has had a drastic impact on satisfaction and confidence of followers (Brockner, 1988; De Cremer, 2003). Sosik, Potosky, and Jung (2002) noted that transformational leadership style was one of the contemporary styles of leadership exercised by leaders who captured their employees' thoughts and opinions into deliberation. Transformational leaders understand their followers' interests, develop consciousness and generate commitment of employees for the benefit of the organization, and allow employees to go beyond their very own self-hobbies for organizational benefits (Seltzer, Numerof, \& Bass, 1989). Transformational leaders act as role models and make their subordinates develop an inspiration; they allow subordinates to convey new ideas and solutions to problems that could make the organization evolve competitively and adjust according to environmental demands. Yang (2009) deliberated on transformational leadership style and suggested that transformational leaders frequently focus on their subordinates' motivation and job performance, suggesting that under these leaders, followers could most likely feel highly satisfied with their jobs.

A number of past studies suggested positive impact of transformational leadership on job satisfaction (al-Dumur \& al-Awamilah, 2002; Bushra et al., 2011; Geyer \& Steyrer, 1994). al-Dumur and al-Awamilah (2002) suggested positive influence of transformational leadership on job satisfaction of bank staff in Jordan. Bushra et al. (2011) suggested similar relationship in context of banking sector staff in Pakistan. Khan et al. (2014) revealed that transformational leadership positively affected employee commitment in service sector of Pakistan. Hanaysha et al. (2012) suggested that intellectual stimulation dimension of transformational leadership positively affected job satisfaction in Malaysian context. In German context, study of Geyer and Steyrer (1994) revealed that core elements of transformational leadership were more strongly connected to bank workers' long term performance. The findings of these studies are largely in line with transformational leadership theory, which suggests that transformational leadership is about acting as role model, developing close productive relations with works, stimulating their creative potential and encouragement that would eventually increase worker satisfaction and motivation. Thus, the discussion leads towards following hypothesis.

H1: Transformational leadership positively influences job satisfaction.

\subsection{Job Design and job satisfaction}

Sukkur IBA Journal of Management and Business - SIJMB | Volume 5 No. 1 January - June 2018 @ Sukkur IBA University 
Job design is about identifying and arranging the tasks, duties, and responsibilities of the job (Opatha, 2002), and so managers must never underestimate the effects of designing jobs on people (Oghojafor \& Adebakin, 2012). As argued earlier, theories in organization behavior have proposed various methods of designing jobs to improve motivation and job satisfaction, such as job enlargement, job enrichment, and job rotation (Herzberg, 1966; Onimole, 2015). Job characteristics model (JCM) suggests that employees feel more motivated and satisfied when their jobs include the characteristics of skill variety, task identity, task significance, autonomy, and feedback (Hackman \& Oldham, 1976). Generally, employees who are happy with their jobs tend to be more satisfied and motivated and this leads them towards high levels of performance as well. Scholars largely claim that job design affects job satisfaction (Fahr, 2011; Onimole, 2015; Sageer et al., 2012). For instance, based on large data set in Germany, Fahr (2011) examined the impact of enriched job based on high autonomy and multitasking features on job satisfaction and found that the evidence supported that hypothesis. Hence, this leads towards following hypothesis.

\section{H2: Job design positively influences job satisfaction.}

\subsection{HR practices and job satisfaction}

HRM is about systems, practices, and policies that persuade behavior, actions, and performance of employees for the betterment of an organization (Gerhart, 2007). A number of past studies empirically examined the effect of HR practices on job satisfaction and other outcomes and majorly revealed that effective use of HR practices would lead towards accomplishing short term and long term goals (Edgar \& Geare, 2005; Syed \& Yan, 2012). Syed and Yan (2012) examined impact of high performance HR practices on job satisfaction in China and found that performance based salary, employee participation, merit based promotion, empowerment, job rotation, and complaint handling procedure had positive link with job satisfaction. Edgar and Geare (2005) studied impact of HR practices on job satisfaction, managerial objectivity, and commitment; and found the impact positive. Petrescu and Simmons (2008) also affirmed positive relation between certain HR practices and job satisfaction. However, Iqbal et al. (2013) reported that manager role had significant impact on job satisfaction, but compensation policy and participation in decision making were insignificant in predicting satisfaction. But, overall, a number of studies argue about positive impact of different HR practices on job satisfaction. This research considers four HR practices for its purpose (compensation practices, promotion practices, empowerment practices, and performance appraisal practices) in line with Mumtaz et al. (2012) as well as based on the assumption that in the context of Pakistan, these practices might be more important to study.

Compensation includes direct as well as indirect rewards; it is a reason for employees to work; and could well determine an employee's living status in society, his satisfaction, loyalty, and other outcomes. Promotion basically refers to one's movement

Sukkur IBA Journal of Management and Business - SIJMB | Volume 5 No. 1 January - June 2018 @ Sukkur IBA University 
towards a higher or better level job. Well-managed organizations develop sound promotion policies for their staff motivation. Researches so far largely argue that good compensation and promotion policies improve job satisfaction (Frye, 2004; Kosteas, 2009). Similarly, employee empowerment is an HR practice, which affects job satisfaction as every individual may not be motivated through financial rewards. Yazdani, Yaghoubi, and Giri (2011) suggested that empowerment was helpful for various businesses in terms of developing satisfaction and belongingness among workers. Humborstad and Perry (2011) conducted research in hospitality industry of China and suggested that employee empowerment leads to better job attitudes including job satisfaction and organizational commitment. Last, performance appraisal is necessary component of HRM, which serves as a base for variety of HR decisions. For this reason, it must be fair, complete, and provide timely feedback. Many scholars have argued that an effective performance appraisal system ensures better organizational output and job satisfaction among workers (Humborstad \& Perry, 2011; Kampkötter, 2017). Importantly, how an organization develops, performs, and updates these HR practices and activities could indicate its intention to develop organizational capabilities in the area of HRM. Therefore, this study also reinforces dynamic capabilities perspective by testing its hypothesis 3 .

\section{H3: HR practices positively influence job satisfaction.}

\section{Research Methodology}

The target population for this research included bank managers and senior staff. To maintain homogeneity, only private banks were included in the study. Primary data was composed for this research because the information regarding the constructs is normally not available through secondary data sources. From the private banks contacted, six consented to participate in the study that included Habib Bank Ltd., Askari Bank Ltd., Muslim Commercial Bank Ltd., Bank Alfalah Ltd., Allied Bank Ltd., and Habib Metropolitan Bank Ltd. The questionnaires were sent to all the branches of these banks in cities including Faisalabad, Kot Addu, Multan, Sadiq abad, and Shah Kot. From 200 questionnaires sent, 170 were returned ( $85 \%$ response rate). This response rate was obtained because questionnaires were delivered personally to respondents and then personal visits and telephone calls were made several times. Past studies where several follow-ups were done also obtained 85\% response rate (Bachrack \& Scoble, 1967; Garcia, Portugal, Chu, \& Kawatkar, 2014).

Questionnaire was constructed by adapting 8 items from the study of Alnaqbi (2011) for measuring job satisfaction which are originally based on Minnesota Satisfaction Questionnaire (Weiss, Dawis, \& England, 1967). For measuring job design, 6 items were selected from the Work Design Questionnaire (Morgeson \& Humphrey, 2006). Transformational leadership was measured by adapting items from previously developed scales such as Transformational Leadership Behavior Inventory (TLI) developed by (Podsakoff, MacKenzie, Moorman, \& Fetter, 1990). HR practices 
consisted of 24 items, out of which 11 items were adapted from the questionnaire developed by Nyaberi (2009) for measuring empowerment practices. For appraisal practices and promotion practices, comprising 5 and 3 items respectively items were adapted using scale of Rathnaweera (2010); 5 items were adopted from the research of Iqbal, Arif, and Abbas (2011) for measuring compensation practices (whose reliability was ensured by previous scholars). The questionnaire included 57 target questions along with 9 questions for classifying respondents into different types. A five point Likert type scale was used to assess the extent of agreement or disagreement for different items.

\section{Data Analyses \& Findings}

\subsection{Measurement model and hypotheses testing}

Data analyses consisted of two models: the measurement model and the structural model. Measurement model was constructed to examine reliability, validity, and other important statistics; whereas, the structural model was constructed for testing the study's hypotheses. The hypotheses were studied using PLS algorithm initially, and later by bootstrapping (with 1000 subsamples). For testing data reliability and validity, guidelines provided by (Garson, 2016) were followed. First, the output of final factor analysis run using measurement model is shown in table 1 . All the factor loadings for final items retained in the model (for reflective constructs) were greater than 0.70 which indicated convergent validity (Henseler, Ringle, \& Sarstedt, 2012). HR practices consisted of certain dimensions and therefore, they were treated as second order formative variable. According to Daskalakis and Mantas (2008), if composite reliability is greater than 0.7, it also shows convergent validity; and this was also accomplished in the model. Cronbach's alpha is one of the frequently used indicators for assessing reliability. Its value has to be greater than 0.6 for ensuring reliability of scale (Cronbach, 1951). Thus, Cronbach's alpha values as well as composite reliability values presented in table 1 show reliability of scales.

Table 1: Measurement Model Analysis

\begin{tabular}{|c|c|c|c|c|c|}
\hline Construct & Items & Loadings & $\begin{array}{l}\text { Composite } \\
\text { Reliability }\end{array}$ & $\begin{array}{l}\text { Cronbach's } \\
\text { alpha }\end{array}$ & AVE \\
\hline \multirow{4}{*}{ Job Satisfaction } & JS1 & 0.763 & \multirow{4}{*}{0.841} & \multirow{4}{*}{0.748} & \multirow{4}{*}{0.569} \\
\hline & JS2 & 0.783 & & & \\
\hline & JS7 & 0.734 & & & \\
\hline & JS8 & 0.736 & & & \\
\hline \multirow{3}{*}{ Job Design } & JD1 & 0.829 & \multirow{3}{*}{0.807} & \multirow{3}{*}{0.641} & \multirow{3}{*}{0.583} \\
\hline & JD2 & 0.726 & & & \\
\hline & JD5 & 0.731 & & & \\
\hline \multirow{4}{*}{$\begin{array}{l}\text { Transformational } \\
\text { Leadership }\end{array}$} & TL1 & 0.738 & \multirow{4}{*}{0.831} & \multirow{4}{*}{0.729} & \multirow{4}{*}{0.552} \\
\hline & TL2 & 0.794 & & & \\
\hline & TL3 & 0.712 & & & \\
\hline & TL12 & 0.724 & & & \\
\hline
\end{tabular}

Sukkur IBA Journal of Management and Business - SIJMB | Volume 5 No. 1 January - June 2018 @ Sukkur IBA University 
Table 1 also shows that the Average Variance Extracted was higher than 0.50 for all variables which shows divergent and convergent validity (Chin, 1998; Garson, 2016). For assessing discriminant validity, Fornell and Larcker (1981) method was used; and the correlation examination of AVEs revealed acceptable results. Additionally, all HTMT (Heterotrait Monotrait) ratios were also less than $0.85(<1.0)$ that showed discriminant validity. Next, the structural model was studied which is shown in figure 1. The model shows three independent variables: transformational leadership, job design, and HR practices; and one dependent variable: job satisfaction. Statistics for test of structural model are given in table 2 .

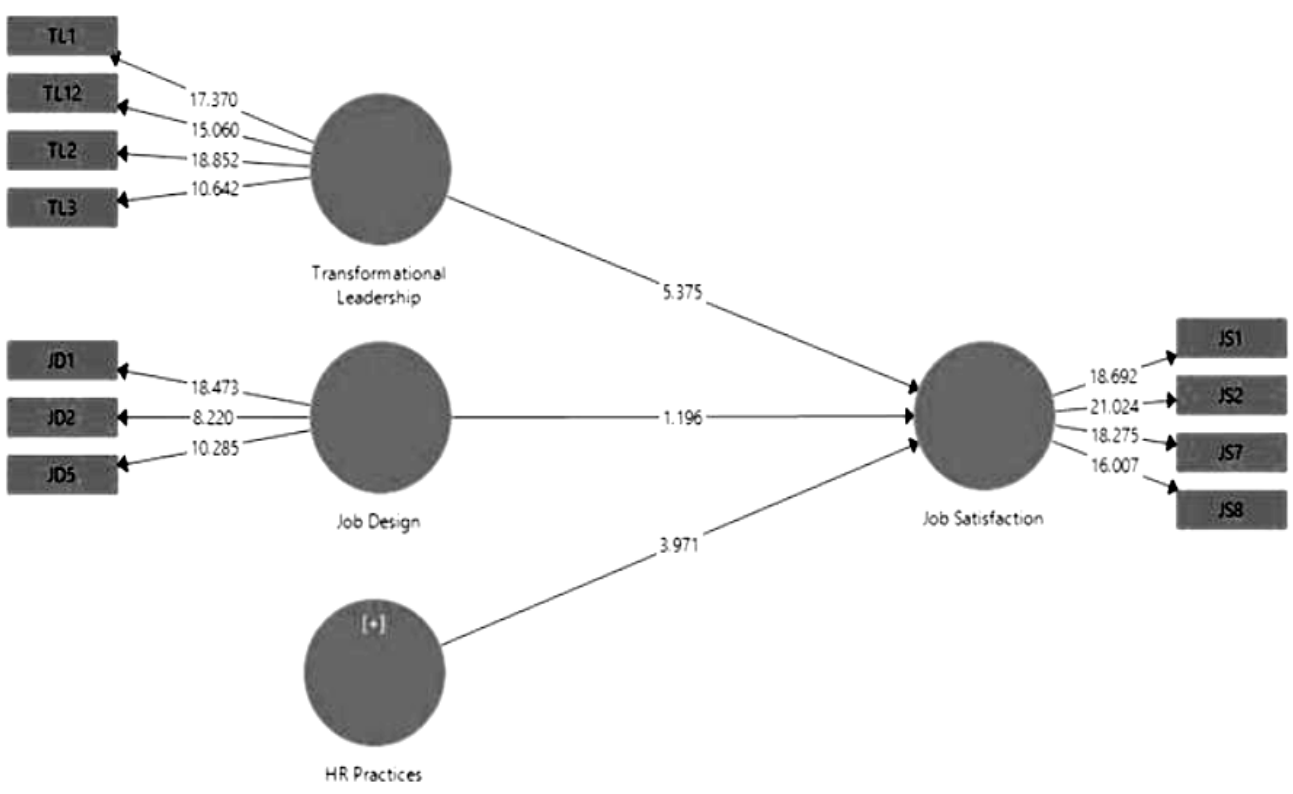

Figure 1: Structural model.

Table 2: Structural Model Analysis

\begin{tabular}{llllll}
\hline \multirow{2}{*}{ Relation } & \multicolumn{2}{l}{ Nature/Significance of effect } & \multicolumn{2}{l}{$\begin{array}{l}\text { Confidence } \\
\text { Interval }\end{array}$} \\
\cline { 2 - 7 } & coefficient & t-values & p-values & $\mathbf{2 . 5 \%}$ & $\mathbf{9 7 . 5 \%}$ \\
\hline $\begin{array}{l}\text { transformational leadership } \rightarrow \\
\text { job satisfaction }\end{array}$ & 0.436 & 5.459 & 0.000 & 0.281 & 0.609 \\
\hline job design $\rightarrow$ job satisfaction & 0.086 & 1.166 & 0.244 & -0.052 & 0.233 \\
\hline $\begin{array}{l}\text { HR practices } \rightarrow \text { job } \\
\text { satisfaction }\end{array}$ & 0.266 & 3.820 & 0.000 & 0.121 & 0.392 \\
\hline
\end{tabular}

Table 2 indicates that transformational leadership has significant effect on job satisfaction (t-value: 5.459, p-value: 0.000 ); hence $\mathrm{H} 1$ is accepted. HR practices also 
has significant effect on job satisfaction (t-value: 3.820 , p-value: 0.000 ) that leads to accepting $\mathrm{H} 3$ also; whereas job design does not have significant effect (t-value: 1.166, p-value: 0.244 ); hence rejecting $H 2 . \mathrm{R}^{2}$ of 0.446 indicates around $45 \%$ variance caused in job satisfaction. Additionally, positive coefficients for effect of transformational leadership and HR practices show that job satisfaction could be increased by better exercising transformational leadership and by improving HR practices.

\subsection{Group differences}

Further analysis was conducted for any significant differences among the opinions of different groups of respondents with respect to gender, age, experience, and qualification. This was accomplished through t-tests and ANOVA. First, t-tests for comparisons among male (115) and female (55) respondents' opinions for the four constructs revealed no significant differences among the two groups for job satisfaction (p-value: 0.911), transformational leadership (p-value: 0.702), job design ( $p$-value: 0.315), and HR practices (p-value: 0.496). Second, ANOVA tests for differences in opinions about transformational leadership showed that there were significant differences among employees belonging to different ages only (p-value: 0.000). ANOVA tests for differences in opinions about job design revealed that there were significant differences among employees belonging to different ages (p-value: 0.000), qualifications (p-value: 0.006), and experience (p-value: 0.000). Next, ANOVA tests for differences in opinions about HR practices also revealed that there were significant differences among employees belonging to different ages (p-value: 0.000), qualifications (p-value: 0.000), and experience (p-value: 0.000). Last, ANOVA tests for differences in opinions regarding job satisfaction also revealed that there were significant differences among employees belonging to different ages ( $p$-value: 0.000), qualifications (p-value: 0.006), and experience (p-value: 0.004). This information carries important implications regarding views of different types of respondents about variables and future researches might therefore, consider including these variables as possible control variables as well.

\section{Conclusion, Discussion, and Implications}

This study tested the effect of transformational leadership, job design, and HR practices on job satisfaction and discovered that transformational leadership and HR practices positively affect job satisfaction of banking staff in Pakistan. The conclusions have support from numerous previous studies. First, the effect of transformational leadership on job satisfaction is supported by many researchers, for instance, by al-Dumur and alAwamilah (2002); and Geyer and Steyrer (1994). This study is particularly in line with that of Bushra et al. (2011) who also reported positive impact of transformational leadership on job satisfaction of bank employees in Pakistan. In other way, this study also supports the conclusions of Riaz, Akram, and Ijaz (2011) and Khan et al. (2014) who reported that positive outcomes like high employee commitment among employees working in Pakistan could be achieved through transformational leadership. Importantly, the results support transformational leadership theory which asserts that 
transformational leaders could enhance employee creativity, motivation, and satisfaction through their charismatic personality, individualized consideration, and by stimulating workers to generate ideas and solve problems.

Secondly, there are many researches that support positive impact of HR practices on job satisfaction (Islam et al., 2016; KoC, Cavus, \& Saraçoglu, 2014; Petrescu \& Simmons, 2008; Syed \& Yan, 2012). HR practices, programs, and activities relate to human resource management in an organization. How an organization performs its various activities concerning performance management, compensation and promotion management, and employee empowerment might serve as its important capabilities to create value within the organization. This value could eventually create value for the buyers and hence, provide competitive advantage to the organization. Therefore, the findings of this study also support and reinforce dynamic capabilities perspective (Teece, Pisano, \& Shuen, 1997).

This study did not find a significant link between job design and job satisfaction. This result came as a surprise given majority research that has already suggested positive impact of job design on job satisfaction. But, Baker (2004), using meta-analysis, also found partial support of job design's impact on job satisfaction. Further, there might be certain reasons behind this finding. First, the design of jobs may not be as important in banking sector as in other sectors. In banks, staff might place more value on factors like type of leadership and HR practices compared to how their jobs are designed. For instance, in banks, staff members may not be able to clearly see the impact of their jobs on the lives of customers, and all the staff members may not be doing a complete module of work or they might be working on a piece of work that could eventually be accomplished with the help of other members in the bank branch. Second, measuring job design through some other method or set of items might produce a different finding. Last, importance and impact of job design in banks might need in depth interviewing and discussion with job incumbents.

This research intends to make important theoretical and practical contribution. First, the theoretical contribution of the study is through its framework. This research tests effects of transformational leadership, job design, and human resource practices on job satisfaction, all in one research framework; and the hypotheses of the model are based on and make contribution to theories of transformational leadership, organization behavior, and dynamic capabilities perspective. Secondly, the study informs Pakistan's banking sector managers on the role of transformational leadership and HR practices for effectively managing job satisfaction of their bank staff. Specifically, it suggests that job satisfaction could be increased if supervisors adopt transformational leadership style wherein they act as role models and construct healthy relations with subordinates, articulate proper vision and communicate it to followers, encourage development of group level goals, instill creativity among subordinates, encourage their initiatives, and provide timely feedback about performance. This study developed HR practices 
construct using four dimensions including compensation practices, promotion practices, performance appraisal practices, and empowerment practices. Therefore, it concludes that job satisfaction is higher when compensation system maintains internal and external equity and offers competitive rewards and incentives. Similarly, it suggests banks' management to design fair performance appraisal system, provide feedback to staff about performance, communicate with staff about methods to appraise performance, and maintain proper record of performance appraisal. The study suggests that promotional policies need also to be formal, fair, and equitable. Last, the findings suggest that banks must ensure participation of staff in decision making and ideas should be taken from all employees for solving problems; practice empowerment and delegation; exercise visionary and effective leadership to create a culture where employees feel encouraged to speak about problems and take initiatives to solve them. It suggests that effective HR practices would help banks satisfy their staff that might ultimately contribute positively to banks' performance.

\section{Limitations and Future Research}

This research has certain limitations which must be acknowledged. First, this study only included private banks in the analyses, and the future research could increase its scope by comparing private banks with public banks on the variables studied herein. Future studies could further increase their scope by including private or public sector banks from all over Pakistan for better generalization. Similar studies in other sectors in Pakistan as well as other parts of the world would surely add to the knowledge on the area. Future researches might think about any intervening variables playing their role in the relationships or any possible moderators for enhanced analyses. Further, the study borrowed items from previous studies for measuring its constructs. Certain other set of items for measuring same constructs could alter the findings; particularly for HR practices, as this study included limited HR practices in the analyses. Future studies could increase the dimensions of HR practices based on their own research designs.

\section{References}

Abid, A. M., Sarwar, A., Imran, K., Jabbar, A., \& Hannan, A. (2013). Effect of job design on employee satisfaction (A study of fertilizer companies listed in Lahore Stock Exchange). European Journal of Business and Management, 5(19), 1-7.

al-Dumur, H., \& al-Awamilah, R. (2002). Effects of transactional and transformational leadership styles of sales managers on job satisfaction and self-perceived performance of sales people: A study of Jordanian manufacturing public shareholding companies. Dirasat: Administrative Sciences Series, 29(1), 247261.

Alnaqbi, W. (2011). The relationship between human resource practices and employee retention in public organisations: an exploratory study conducted in the United

Sukkur IBA Journal of Management and Business - SIJMB | Volume 5 No. 1 January - June 2018 @ Sukkur IBA University 
Arab Emirates. (Unpublished Doctoral Thesis). Edith Cowan University, Australia.

Appelbaum, E., Bailey, T., Berg, P. B., \& Kalleberg, A. L. (2000). Manufacturing advantage: Why high-performance work systems pay off: NY: Cornell University Press.

Bachrack, S. D., \& Scoble, H. M. (1967). Mail questionnaire efficiency: Controlled reduction of nonresponse. The Public Opinion Quarterly, 31(2), 265-271.

Baker, W. K. (2004). Antecedents and consequences of job satisfaction: Testing a comprehensive model using integrated methodology. Journal of Applied Business Research, 20, 31-44.

Bass, B. M. (1985). Leadership and performance beyond expectations. NY: Free Press.

Brockner, J. (1988). Self esteem at work. MA: D.C. Health and Company.

Burns, J. M. (1978). Leadership. NY: Harper \& Row.

Bushra, F., Ahmad, U., \& Naveed, A. (2011). Effect of transformational leadership on employees' job satisfaction and organizational commitment in banking sector of Lahore (Pakistan). International journal of Business and Social science, 2(18), 261-267.

Chin, W. W. (1998). The partial least squares approach to structural equation modeling. In G.A. Marcoulides (Ed.), Modern methods for business research (pp. 295336). NJ: Lawrence Erlbaum Associates.

Conley, S. C. (1989). " Who's on First?" school reform, teacher participation, and the decision-making process. Education and Urban Society, 21(4), 366-379.

Cronbach, L. J. (1951). Coefficient alpha and the internal structure of tests. Psychometrika, 16(3), 297-334.

Daskalakis, S., \& Mantas, J. (2008). Evaluating the impact of a service-oriented framework for healthcare interoperability. Studies in Health Technology and Informatics, 136, 285-290.

De Cremer, D. (2003). Why inconsistent leadership is regarded as procedurally unfair: The importance of social self-esteem concerns. European Journal of Social Psychology, 33(4), 535-550.

Edgar, F., \& Geare, A. (2005). HRM practice and employee attitudes: Different measures-different results. Personnel Review, 34(5), 534-549.

Fahr, R. (2011). Job design and job satisfaction-empirical evidence for Germany? management revue, 22(1), 28-46.

Fornell, C., \& Larcker, D. F. (1981). Structural equation models with unobservable variables and measurement error: Algebra and statistics. Journal of Marketing Research, 18(3), 382-388.

Frye, M. B. (2004). Equity-based compensation for employees: Firm performance and determinants. Journal of Financial Research, 27(1), 31-54.

Garcia, I., Portugal, C., Chu, L. H., \& Kawatkar, A. A. (2014). Response rates of three modes of survey administration and survey preferences of rheumatoid arthritis patients. Arthritis Care \& Research, 66(3), 364-370.

Sukkur IBA Journal of Management and Business - SIJMB | Volume 5 No. 1 January - June 2018 @ Sukkur IBA University 
Garson, G. (2016). Partial least squares: Regression and structural equation models. USA: Statistical Publishing Associates.

Gerhart, B. (2007). Modeling HRM and performance linkages. In P. Boxall, J. Purcell, \& P. Wright (Eds.), The (Oxford) handbook of human resource management (pp. 552-580). UK: Oxford University Press.

Geyer, A. L., \& Steyrer, J. (1994). Transformationale Führung, klassische Führungstheorien und Erfolgsindikatoren von Bankbetrieben. Zeitschrift für Betriebswirtschaft, 64(8), 961-979.

Hackman, J. R., \& Oldham, G. R. (1976). Motivation through the design of work: Test of a theory. Organizational Behavior and Human Performance, 16(2), 250279.

Hanaysha, J., Khalid, K., Mat, N., Sarassina, F., Rahman, M., \& Zakaria, A. (2012). Transformational leadership and job satisfaction. American Journal of Economics, Special Issue, 145-148.

Henseler, J., Ringle, C. M., \& Sarstedt, M. (2012). Using partial least squares path modeling in international advertising research: Basic concepts and recent issues. In S. Okzaki (Ed.), Handbook of partial least squares: Concepts, methods and applications in marketing and related fields (pp. 252-276). Berlin: Springer.

Herzberg, F. I. (1966). Work and the nature of man. Cleveland: World Publishing.

Hoy, W. K., \& Miskel, C. G. (1987). Educational administration: Theory, research, and practice ( $3 r d$ ed.). NY: Random House.

Humborstad, S. I. W., \& Perry, C. (2011). Employee empowerment, job satisfaction and organizational commitment: An in-depth empirical investigation. Chinese Management Studies, 5(3), 325-344.

Iliescu, D., Beldean, F., \& Sîntion, F. (2007). MLQ-Multifactor Leadership Questionnaire: Technical and interpretative manual. Cluj-Napoca: Sinapsis.

Iqbal, H., Malik, M., \& Ghafoor, M. (2013). Impact of HR practices on job satisfaction: An empirical evidence from corporate sector of Punjab-Pakistan. Interdisciplinary Journal of Contemporary Research in Business, 5(2), 442454.

Iqbal, M. Z., Arif, M. I., \& Abbas, F. (2011). HRM practices in public and private universities of Pakistan: A comparative study. International Education Studies, 4(4), 215-222.

Islam, Z., Bangish, S. B., Muhammad, H., \& Jehan, A. S. (2016). The impact of HR practices on job satisfaction: A case study of hotel industry in Pakistan. The Journal of Asian Finance, Economics and Business, 3(1), 43-48.

Kampkötter, P. (2017). Performance appraisals and job satisfaction. The International Journal of Human Resource Management, 28(5), 750-774.

Khan, M. I., Awan, U., Yasir, M., Mohamad, N. A. B., Shah, S. H. A., Qureshi, M. I., \& Zaman, K. (2014). Transformational leadership, emotional intelligence and organizational commitment: Pakistan's services sector. Argumenta Oeconomica, 33(2), 67-92.

Sukkur IBA Journal of Management and Business - SIJMB | Volume 5 No. 1 January - June 2018 @ Sukkur IBA University 
KoC, M., Cavus, M. F., \& Saraçoglu, T. (2014). Human resource management practices, job satisfaction and organizational commitment. International Journal of Academic Research in Business and Social Sciences, 4(9), 178-190.

Kosteas, V. D. (2009). Job satisfaction and promotions. Industrial Relations, 50(1), 174-194.

Michaels, R. (2017, May 11). The outlook of the banking industry in Pakistan. Retrieved January 12, 2018, from https://internationalbanker.com/banking/outlookbanking-industry-pakistan.

Morgeson, F. P., \& Humphrey, S. E. (2006). The Work Design Questionnaire (WDQ): Developing and validating a comprehensive measure for assessing job design and the nature of work. Journal of Applied Psychology, 91(6), 1321-1339.

Mumtaz, A., Khan, I., Aslam, H. D., \& Ahmad, B. (2012). Impact of HR practices on job satisfaction of university teacher: Evidence from universities in Pakistan. Industrial Engineering Letters, 1(3), 10-17.

Nabi, M. N., Syduzzaman, M., \& Munir, M. S. (2016). The impact of human resource management practices on job performances: A case study of Dhaka Bank Pvt. Ltd., Bangladesh. Human Resource Management Research, 6(2), 45-54.

Nyaberi, D. O. (2009). An arts-based educational framework for fostering intercultural unity in Kenya: University of Illinois at Urbana-Champaign.

Oghojafor, B. A., \& Adebakin, M. A. (2012). Assessment of job design and job satisfaction among doctors and nurses in Lagos, Nigeria hospitals. African Journal of Business Management, 6(48), 11702-11706.

Onimole, S. (2015). Work design and job satisfaction. International Journal of Humanities and Social Science, 5(10), 202-207.

Opatha, H. (2002). Performance evaluation of human resources ( $1^{\text {st }}$ ed.). Colombo: Author publication.

Petrescu, A. I., \& Simmons, R. (2008). Human resource management practices and workers' job satisfaction. International Journal of Manpower, 29(7), 651-667.

Podsakoff, P. M., MacKenzie, S. B., Moorman, R. H., \& Fetter, R. (1990). Transformational leader behaviors and their effects on followers' trust in leader, satisfaction, and organizational citizenship behaviors. The Leadership Quarterly, 1(2), 107-142.

Rathnaweera, R. R. N. T. (2010). Do HRM practices impact employee satisfaction, commitment, or retention? Empirical studies of Sri Lankan public sector banks). (Master Thesis). University of Agder, Norway.

Riaz, T., Akram, M. U., \& Ijaz, H. (2011). Impact of transformational leadership style on affective employees' commitment: An empirical study of banking sector in Islamabad (Pakistan). The Journal of Commerce, 3(1), 43-51.

Sageer, A., Rafat, S., \& Agarwal, P. (2012). Identification of variables affecting employee satisfaction and their impact on the organization. IOSR Journal of Business and Management, 5(1), 32-39.

Savickas, M. L., \& Savickas, S. (2016). Vocational psychology, overview.

Sukkur IBA Journal of Management and Business - SIJMB | Volume 5 No. 1 January - June 2018 @ Sukkur IBA University 
Seltzer, J., Numerof, R. E., \& Bass, B. M. (1989). Transformational leadership: Is it a source of more burnout and stress? Journal of Health and Human Resources Administration, 12(2), 174-185.

Sosik, J. J., Potosky, D., \& Jung, D. I. (2002). Adaptive self-regulation: Meeting others' expectations of leadership and performance. The Journal of Social Psychology, 142(2), 211-232.

Spector, P. E. (1997). Job satisfaction: Application, assessment, causes, and consequences (Vol. 3). CA: Sage Publications.

Syed, N., \& Yan, L. X. (2012). Impact of high performance human resource management practices on employee job satisfaction: Empirical analysis. Interdisciplinary Journal of Contemporary Research in Business, 4(2), 318342.

Teece, D. J., Pisano, G., \& Shuen, A. (1997). Dynamic capabilities and strategic management. Strategic Management Journal, 18(7), 509-533.

Vroom, V. (1964). Work and motivation. NY: John Willey \& Sons.

Weiss, D. J., Dawis, R. V., \& England, G. W. (1967). Manual for the Minnesota satisfaction questionnaire. Minneapolis: University of Minnesota.

Yang, Y.-F. (2009). An investigation of group interaction functioning stimulated by transformational leadership on employee intrinsic and extrinsic job satisfaction: An extension of the resource-based theory perspective. Social Behavior and Personality: An International Journal, 37(9), 1259-1277.

Yazdani, B., Yaghoubi, N., \& Giri, E. (2011). Factors affecting the empowerment of employees: An empirical study. European Journal of Social Science, 20(2), 267-274. 